\title{
Pseudomonas tolaasii bacteriophage-specific polyclonal antibody formation and its cross reactivity to various phages
}

\author{
Yeong-Bae Yun ${ }^{1}$ (D) $\cdot$ Soo-Jin Park ${ }^{1}$ (D) $\cdot$ Young-Kee Kim ${ }^{1}$ \\ Pseudomonas tolaasii 박테리오파지에 특이적인 다클론항체 형성 및
이를 이용한 파지 교차 반웅성
}

윤영 배 ${ }^{1} \cdot$ 박수진 $^{1} \cdot$ 김영기 $^{1}$

Received: 17 July 2019 / Accepted: 26 August 2019 / Published Online: 30 September 2019

(C) The Korean Society for Applied Biological Chemistry 2019

\begin{abstract}
Pseudomonas tolaasii causes brown blotch disease on the oyster mushroom (Pleurotus ostreatus). Various pathogenic strains of $P$. tolaasii were isolated and divided into three subtypes, $\mathrm{P} 1 \alpha, \mathrm{P} 1 \beta$, and $\mathrm{P} 1 \gamma$. For phage therapy, bacteriophages against to these subtype strains were applied to mushroom cultivation and very successful to prevent from the disease. In this study, bacteriophages were isolated against the representative strains of subtype pathogens and their polyclonal antibodies were synthesized to investigate structural relationship among capsid proteins of phages. Phage preparations over $10^{10} \mathrm{pfu} / \mathrm{mL}$ were injected to rabbit thigh muscle and polyclonal antibodies were obtained after three times of boost injection. Titers of the antibodies obtained were over $2 \times 10^{7} \mathrm{Ab} / \mathrm{mL}$ for the phage $\phi 6264,1 \times 10^{6} \mathrm{Ab} / \mathrm{mL}$ for the phage $\phi \mathrm{HK} 2$, and $1 \times 10^{7} \mathrm{Ab} / \mathrm{mL}$ for the phage $\phi \mathrm{HK} 19$ and phage $\phi \mathrm{HK} 23$. High specific activities were observed between antibodies and the corresponding bacteriophages. Some crossreactivities between the antibodies and non-corresponding bacteriophages were also measured. Antibody Ab 6264 inactivated all phages of $\mathrm{P} 1 \alpha$ subtype and only phage $\phi \mathrm{HK} 16$ among $\mathrm{P} 1 \beta$
\end{abstract}

Young-Kee $\operatorname{Kim}(\triangle)$

E-mail: ykkim10@cbnu.ac.kr

${ }^{1}$ Department of Environmental and Biological Chemistry, Chungbuk National University, Cheongju, Chungbuk 28644, Republic of Korea

This is an Open Access article distributed under the terms of the Creative Commons Attribution Non-Commercial License (http://creativecommons. org/licenses/by-nc/3.0/) which permits unrestricted non-commercial use, distribution, and reproduction in any medium, provided the original work is properly cited. subtype phages. Antibody Ab $\phi \mathrm{HK} 23$ of $\mathrm{P} 1 \gamma$ subtype neutralized all phages of P1 $\beta$ subtype as well as the phage $\phi \mathrm{HK} 23$, showing the widest phage-inactivation range. When the structural-similarity studies of phages were investigated by using phage antibodies, closeness obtained by phylogenetic analysis of $16 \mathrm{~S}$ rRNA genes of pathogenic strains were quite different from that of polyclonal antibody-specific structural similarity of phage capsid proteins. In conclusion, there is weak correlation between the host strain specificity of bacteriophage and its capsid structural similarity measured by phage antibodies.

Keywords Antibody Bacteriophage $\cdot$ Brown blotch disease Close relationship $\cdot$ Phage-host range $\cdot$ Pseudomonas tolaasii

\section{서 론}

느타리버섯은 단위 면적당 수익성이 가장 높은 작물 중 하나이 며, 다양한 생리활성 물질을 함유하는 것이 확인되어 약용 및 건강식품으로 널리 사용되고 있다[1]. 특히, $\omega-3$ 지방산을 함유 하고 있어 항산화 또는 항염증 효능과 체지방을 감소시켜 성인 병 예방 등의 효과가 있는 것으로 밝혀졌다[2,3]. 이러한 이점 에도 불구하고 재배시 세균성 갈반병(brown blotch disease)의 빈번한 발생으로 느타리버섯의 재배면적은 해마다 감소하고 있 다. 갈반병은 주로 병원성 세균인 Pseudomonas tolaasi가 분비 하는 펩티드 독소인 tolaasin과 유사한 펩티드들에 의해 발생한 다[4,5]. 갈반병을 유발하는 병원균에 대한 정확한 전염경로나 효과적인 방제법이 현재까지 확립되어 있지 않기에 발병시 버 
섯재배 농가의 경제적 피해가 매우 크다. 그럼에도 불구하고 건 강식품인 버섯류의 특성상 병 방제를 위한 항생제 및 살균제 농약의 사용이 제한되어 있어 재배가 어려운 실정이다.

최근 농약사용에 따른 잔류독성 위험성과 항생제 내성균의 발생에 따른 효과감소 등으로 세균의 바이러스인 박테리오파지 를 이용하여 세균을 사멸시키는 파지테라피 방법이 실용화되고 있다[6]. 파지테라피는 병원균을 숙주균으로 감염할 수 있는 파 지들을 선발하고, 이를 혼합한 칵테일 형태로 처리하여 다양한 변이균을 포함한 병원균을 효과적이고 강력하게 사멸시켜 병발 생을 억제하는 방법이다. 파지는 효과적인 항생제가 없는 병원 성 세균에도 큰 방제효과를 보이며, 항생제에 내성을 갖는 약 제내성 세균들도 효과적으로 방제할 수 있는 장점을 갖는다[7].

갈반병 병원균주들을 $16 \mathrm{~S}$ rRNA 유전자 분석을 통하여 분류 하였을 때, P. tolaasii 균주들은 세 가지 그룹으로 나뉘어 $\mathrm{P} 1 \alpha$, $\mathrm{P} 1 \beta, \mathrm{P} 1 \gamma$ 로 분류하였다. 이들 그룹은 계통수(phylogenetic tree) 상에서 매우 근접하게 위치하였으나, 대조 균주(reference strain) 인 P. tolaasii ATCC 33618균주와의 상동성에서 차이를 보였다 [8]. 총 23종의 P. tolaasii 병원균을 재배 농장에서 채취하여 분 류하였을 때, $\mathrm{P} 1 \alpha$ 그룹에는 P. tolaasii 6264균을 비롯한 6종의 균 주가 속하며, P1 그룹에는 16 종, P $1 \gamma$ 그룹에는 1 종이 속하였다.

갈반병 방제를 위한 파지테라피 방법을 개발하기 위해서는 그룹별 병원균을 공격하는 파지들을 분리 동정하고 분류하여 숙 주 범위가 넓은 다양한 파지를 확보하여야 한다. 파지의 분류 를 위해서는 숙주역의 범위나 파지유전자의 분석 등과 더불어 항체를 이용한 파지의 구조적 연관성 여부를 조사하여야 한다. 항체(antibody)는 항원 물질과 특이적으로 결합하여 비활성화시 키는 특성을 갖는 당단백질로, 박테리오파지를 항원으로 실험동 물체에 주사하면 파지의 capsid 단백질 구조를 인식하여 항체 가 생성된다[9]. 항체는 파지의 껍질단백질 구조에 따른 파지 사이의 구조적 유사성을 연구하는데 좋은 도구가 될 수 있으며, 다양한 파지를 혼합하는 파지칵테일 제조시에 유용한 파지의 분 류기준이 된다.

선행 연구에서 갈반병 균주들을 숙주균으로 하는 파지를 분 리하여 이들의 숙주역을 조사하였다. 20종 이상의 P. tolaasii균 주와 이들 균주를 사멸시킬 수 있는 파지의 조합으로 혼합액을 처리하였을 때 파지에 의한 병원균주 사멸효과가 매우 큼을 확 인하였다[10]. 본 연구에서는 갈반병균의 분류별로 $\mathrm{P} 1 \alpha, \mathrm{P} 1 \beta$, $\mathrm{P} 1 \gamma$ 에 속하는 독성 파지를 항원으로 하는 다클론항체(polyclonal antibody)를 제작하여 각 항체에 의한 파지 억제 효과를 확인하 였다. 파지의 다클론항체는 파지의 구조를 이루는 다양한 항원 결정부위에 대한 항체의 혼합물로 구성되어 있어 다양한 독성 파지를 capsid 단백질 항원적 특성에 따라 분류가 가능하여 동 일한 숙주역을 갖는 파지일지라도 항체를 이용한 구별이 가능 하다. 따라서, 서로 다른 그룹에 속한 파지들의 항체 반응성 분 석을 통하여 항체가 인식하는 부위인 capsid 단백질 구조의 유 사성에 따른 상호 연관성을 조사하였다.

\section{재료 및 방법}

\section{파지의 분리}

파지는 선행연구에서 청주시 생활하수 하천과 버섯 재배 농가에
서 배출하는 침출액에서 agar 이중층 방법으로 플라크를 생성시 켜 파지를 분리하였다. Agar 이중층은 숙주균과 하천 샘플을 $1: 1$ 의 비율로 soft agar 배지에 각각 접종한 후 hard agar 배지 에 부어 만들었다[11]. 접종을 완료한 agar 이중층 배지는 $25^{\circ} \mathrm{C}$ 에서 15 시간 동안 배양하였다. 파지의 순수분리와 증폭은 멸균한 바늘로 한 개의 파지 플라크를 채취한 후 Pseudomonas agar $\mathrm{F}$

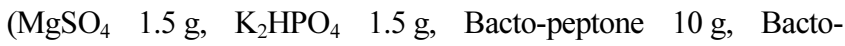
tryptone $10 \mathrm{~g}$, agar $15 \mathrm{~g}$, glycerol $10 \mathrm{~mL}$ per liter) 액체배지 $5 \mathrm{~mL}$ 에 현탁시키고 각 파지 숙주균을 가하여 24시간 배양하여 이루어졌다.

파지 입자의 분리는 Chibani-Chennoufi 등[12]의 방법에 따라 숙주균과 함께 배양한 파지 용균액에 $\mathrm{NaCl}$ 을 용균액의 $10 \%$ 가 되도록 첨가하고, $0{ }^{\circ} \mathrm{C}$ 에서 1 시간 동안 배양하여 $8,000 \mathrm{rpm}$ 에서 10 분간 원심분리하였다. 원심분리를 통해 얻은 상징액에 $10 \%$ polyethyleneglycol (PEG) 6000을 처리하고 $0{ }^{\circ} \mathrm{C}$ 에서 1 시간 동 안 배양한 후 $12,000 \mathrm{rpm}$ 에서 10 분간 원심분리하여 파지를 침전 시켰다. PEG 6000에 의해 침전된 파지는 파지완충액 $(50 \mathrm{mM}$ Tris- $\mathrm{HCl}, 150 \mathrm{mM} \mathrm{NaCl}, 20 \mathrm{mM} \mathrm{NH}_{4} \mathrm{Cl}, 10 \mathrm{mM} \mathrm{MgCl}_{2}$, $1 \mathrm{mM} \mathrm{CaCl} 2, \mathrm{pH} 7.3$ )에 재현탁하여 $-80^{\circ} \mathrm{C}$ 에 보관하였다.

\section{다클론항체의 생산, 계수 측정 및 교차반웅}

다클론항체(polyclonal antibody)의 제작은 70일령의 암컷 New Zealand White rabbit을 사용하여 이루어졌다. 항원 물질은 항 체 생산을 위하여 농축한 파지 $\left(10^{11}-10^{12} \mathrm{pfu} / \mathrm{mL}\right)$ 와 항원보조 제(Freund's adjuvant)를 1:1 (v/v)의 비율로 혼합하여 토끼의 목 뒤와 뒷다리의 근육에 주사하였다[13]. 첫 면역화 반응은 1차 주사에서 파지와 Freund's complete adjuvant를 혼합하여 유도 하고[14], 2차와 3차 boost injection을 통한 면역화에서는 파지 와 Freund's incomplete adjuvant를 혼합하여 유도하였다. 생성 된 항체의 측정은 항원을 주사하고 7일 후에 토끼의 귀 정맥에 서 혈액을 채취하여 이루어 졌다.

항체의 계수(titer) 측정은 파지용균액을 희석하여 배지당 300 plaques 정도를 형성하도록 희석 배수를 결정한 후 이루어졌다. 항원-항체 반응은 다클론항체를 포함한 혈청과 희석된 파지를 서로 혼합하고 상온에서 정치하여 유도하였다. 항원과 항체가 반응한 혼합액을 숙주균에 처리하고, 15 시간 배양 후 반응하지 않은 파지의 수를 측정하여 항체에 의해 감소한 파지의 수를 결정하여 항체의 titer로 하였다. 3 차 면역화에서 2 주 경과 후에 다클론항체는 토끼의 심장에서 채혈하여 최종 수확하고 항혈청 중 항체의 계수를 측정하였다. 항체를 포함한 혈청은 $-80{ }^{\circ} \mathrm{C}$ 에 보관하며 사용하였다.

다양한 파지와 다클론항체를 교차반응시키기 위하여 파지액 은 식염수에 희석하여 이중층 방법으로 도말하여 계수를 측정 하였다. 적절한 희석 배수가 선정된 파지는 희석한 다클론항체 와 각각 혼합하고, 파지-항체 혼합액은 상온에서 2 시간 동안 정 치하여 충분히 항원-항체 반응을 일으켜 결합하게 하였다. 이중 층 방법으로 파지-항체 혼합액을 도말하여 $25^{\circ} \mathrm{C}$ 에서 15 시간동 안 배양하여 $\mathrm{pfu}$ 를 측정하였다.

\section{버섯조직함몰검정법(Pitting test)}

버섯조직함몰검정법은 양송이버섯을 이용하여 수행하였다. 양송 이버섯의 갓 부분과 자루 부분을 절단하여 수평을 이루게 하고 
갓 부분의 절단면에 배지(control), 균주 배양액 $\left(10^{8}-10^{9} \mathrm{cfu} / \mathrm{mL}\right)$, 균주배양액 + 파지, 균주배양액+파지액+항체, 균주배양액+항체를 각각 $10 \mu \mathrm{L}$ 씩 점적하여 흡수시켰다. 각 용액을 점적한 버섯은 $12-24$ 시간 동안 $25^{\circ} \mathrm{C}$ 에서 배양하였다. 배양 중 증류수로 적신 여과지를 넣고 밀봉하여 수분 증발을 방지하였다. 반응에 대한 평가는 점적부위의 변색과 함몰 정도를 관찰하여 이루어졌다.

\section{결과 및 고찰}

\section{박테리오파지에 대한 항체 생산}

항체의 생산은 고농도의 파지액과 항원보조제(Freund's adjuvant) 의 혼합액을 토끼의 근육 및 피하에 주입하여 이루어졌다. 다 클론항체의 역가는 토끼에 파지항원액을 1 차 주사하여 면역화 하였을 때, $10^{4} \mathrm{Ab} / \mathrm{mL}$ 이상으로 증가하였고, 2차 주사하였을 때에는 $10^{5} \mathrm{Ab} / \mathrm{mL}$ 이상 증가하였다(Fig. 1). 최종적으로 항체 는 3 차 주사를 통하여 $10^{7} \mathrm{Ab} / \mathrm{mL}$ 이상 증가하였을 때, 채혈하 여 얻었다. 항원으로 사용한 파지는 숙주균의 소그룹에 따라 $\mathrm{P} 1 \alpha$ 그룹의 $\phi 6264$ 와 $\phi \mathrm{HK} 2, \mathrm{P} 1 \beta$ 소그룹의 $\phi \mathrm{HK} 19, \mathrm{P} 1 \gamma$ 소그 룹의 $\phi \mathrm{HK} 23$ 이 선발되었다. 최종적으로 얻은 항체들 중 $\phi 6264$ 에 대한 항체 $\mathrm{Ab} \phi 6264$ 는 $2.0 \times 10^{7} \mathrm{Ab} / \mathrm{mL}$ 이상, $\phi \mathrm{HK} 19$ 에 대한 항체 $\mathrm{Ab} \phi \mathrm{HK} 19$ 와 $\phi \mathrm{HK} 23$ 에 대한 항체 $\mathrm{Ab} \phi \mathrm{HK} 23$ 은 $1.0 \times 10^{7}$ $\mathrm{Ab} / \mathrm{mL}$ 이상의 활성으로 수확하였으나, $\phi \mathrm{HK} 2$ 에 대한 항체 $\mathrm{Ab} \phi \mathrm{HK} 2$ 는 다른 다클론항체와 비교하여 낮은 $1.0 \times 10^{6} \mathrm{Ab} / \mathrm{mL}$ 이상으로 수확하였다. 수확한 다클론항체는 해당 파지에 매우 특이적으로 작용하였고, 파지는 항체와의 결합시 갈반병균에 대 한 공격력을 완전하게 잃어버렸다.

\section{Pitting test에서의 항체에 의한 파지 억제 효과}

다클론항체는 항체 생산에 사용한 파지와 강하게 항원-항체 반 응을 하여 파지를 불활성화하였다. 갈반병 원인균주 $P$. tolaasii 6264, P. tolaasii HK2, P. tolaasii HK23은 버섯표면에 접종시 갈반을 심하게 형성하였으나, 각 균주에 특이적인 파지를 처리

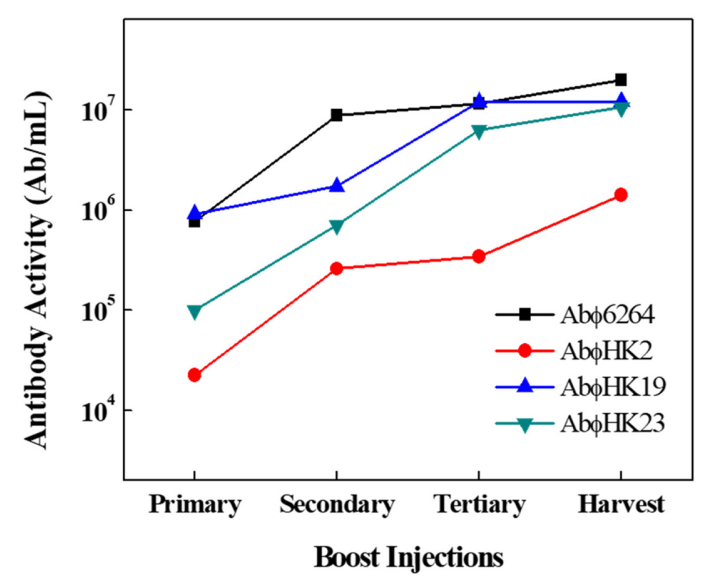

Fig. 1 Increase in antibody titers by boost injections. Phages were mixed with Freund's complete adjuvant at 1st injection and with Freund's incomplete adjuvant at 2nd and 3rd boost injections. Titer of antibody was measured at 1 week after each boost injection

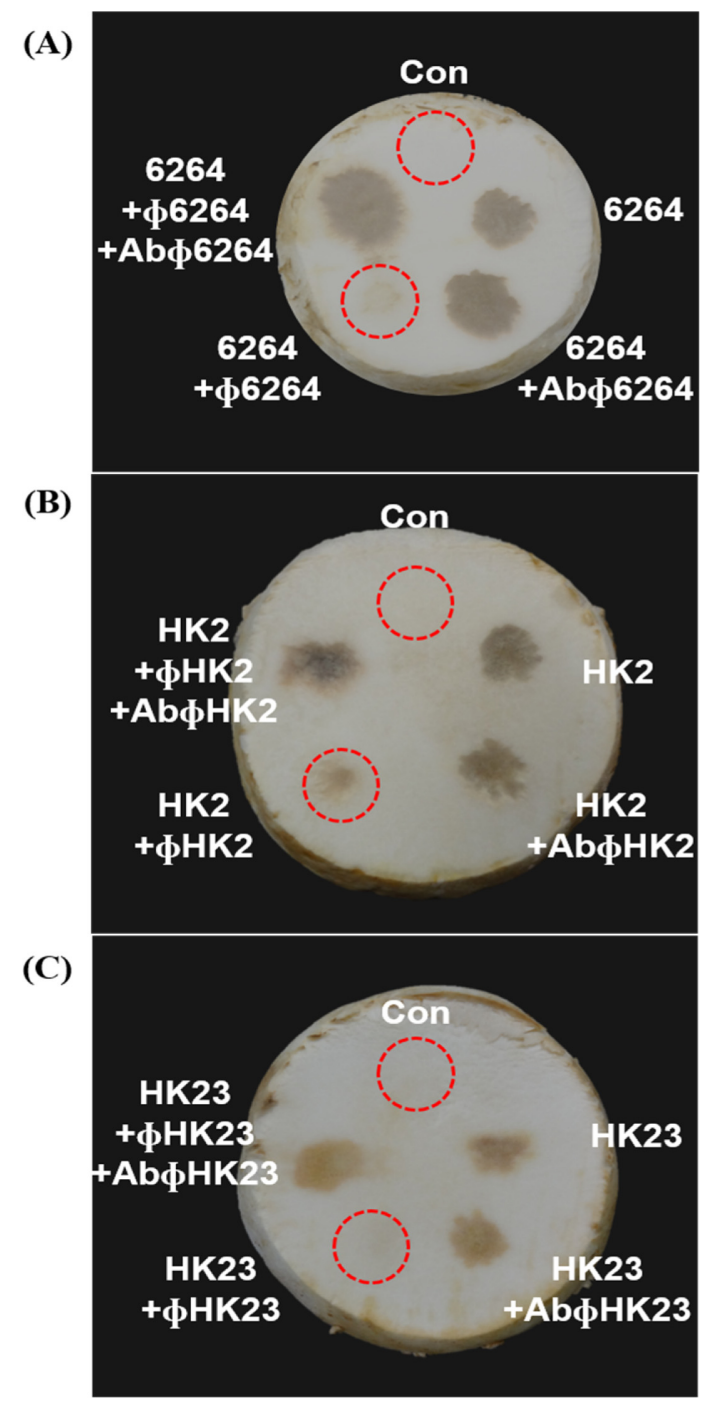

Fig. 2 Effects of phages and antibodies on brown blotch formation by pathogenic strains. Pathogens were inoculated with or without their corresponding phages and polyclonal antibodies on the surface of mushroom. (A) P. tolaasii 6264, (B) P. tolaasii HK2, and (C) P. tolaasii HK23

한 경우에는 이들 균주에 의한 갈반형성이 완전히 억제되었다 (Fig. 2). 또한, 갈반병 원인균주와 특이적인 파지, 그리고 해당 파지의 항체를 처리한 경우에는 항체에 의해 파지가 불활성화 됨으로써 병원균에 의한 병발생을 억제하지 못하여 갈반이 형 성되었다. 이러한 결과를 통해, 항체가 존재할 경우에는 파지항체 반응에 의한 파지의 불활성화로 병원균에 의한 갈반 형성 은 저해되지 않았다. 반면, 각 병원균주와 다클론항체를 동시에 처리한 경우에는 갈반형성이 관측되어 파지의 항체는 갈반병 균 주와 상호작용하지 않음을 확인하였다. 이러한 결과는 소그룹별 파지 항체를 이용한 모든 실험에서 동일하게 나타났다. 이는 버 섯표면에서 파지의 항체가 숙주균의 존재와 관계없이 특이적인 파지와 항원-항체 반응을 일으키며, 다클론항체가 버섯재배 환 경에서도 특이적으로 해당 파지를 저해할 수 있음을 보였다. 
Table 1 Cross-reactivities of phages and polyclonal antibodies

\begin{tabular}{|c|c|c|c|c|c|c|c|c|c|}
\hline \multirow{2}{*}{ Antibody } & \multirow[t]{2}{*}{ Phage } & \multicolumn{3}{|c|}{$\mathrm{P} 1 \alpha$} & \multicolumn{4}{|c|}{$\mathrm{P} 1 \beta$} & \multirow{2}{*}{$\begin{array}{c}\mathrm{P} 1 \gamma \\
\phi \mathrm{HK} 23\end{array}$} \\
\hline & & $\phi 6264$ & $\phi \mathrm{HK} 1$ & $\phi \mathrm{HK} 2$ & $\phi \mathrm{HK} 19$ & $\phi \mathrm{HK} 7$ & $\phi \mathrm{HK} 16$ & $\phi \mathrm{HK} 22$ & \\
\hline \multirow{2}{*}{$\mathrm{P} 1 \alpha$} & Ab $\phi 6264$ & (O) & $\bigcirc$ & $\bigcirc$ & $x$ & $\times$ & $\bigcirc$ & $x$ & $x$ \\
\hline & $\mathrm{Ab} \phi \mathrm{HK} 2$ & $x$ & $x$ & (a) & $x$ & $\bigcirc$ & $\times$ & $\bigcirc$ & $\bigcirc$ \\
\hline$P 1 \beta$ & AbфHK19 & $\times$ & $\times$ & $\times$ & (C) & $\times$ & $\times$ & $\times$ & $\bigcirc$ \\
\hline $\mathrm{P} 1 \gamma$ & Ab $\phi H K 23$ & $x$ & $\times$ & $\times$ & $\bigcirc$ & $\bigcirc$ & $\bigcirc$ & $\bigcirc$ & (a) \\
\hline
\end{tabular}

$\bigcirc$ : complete inactivation, $\times$ : no inactivation, (): corresponding bacteriophage for the production of antibody

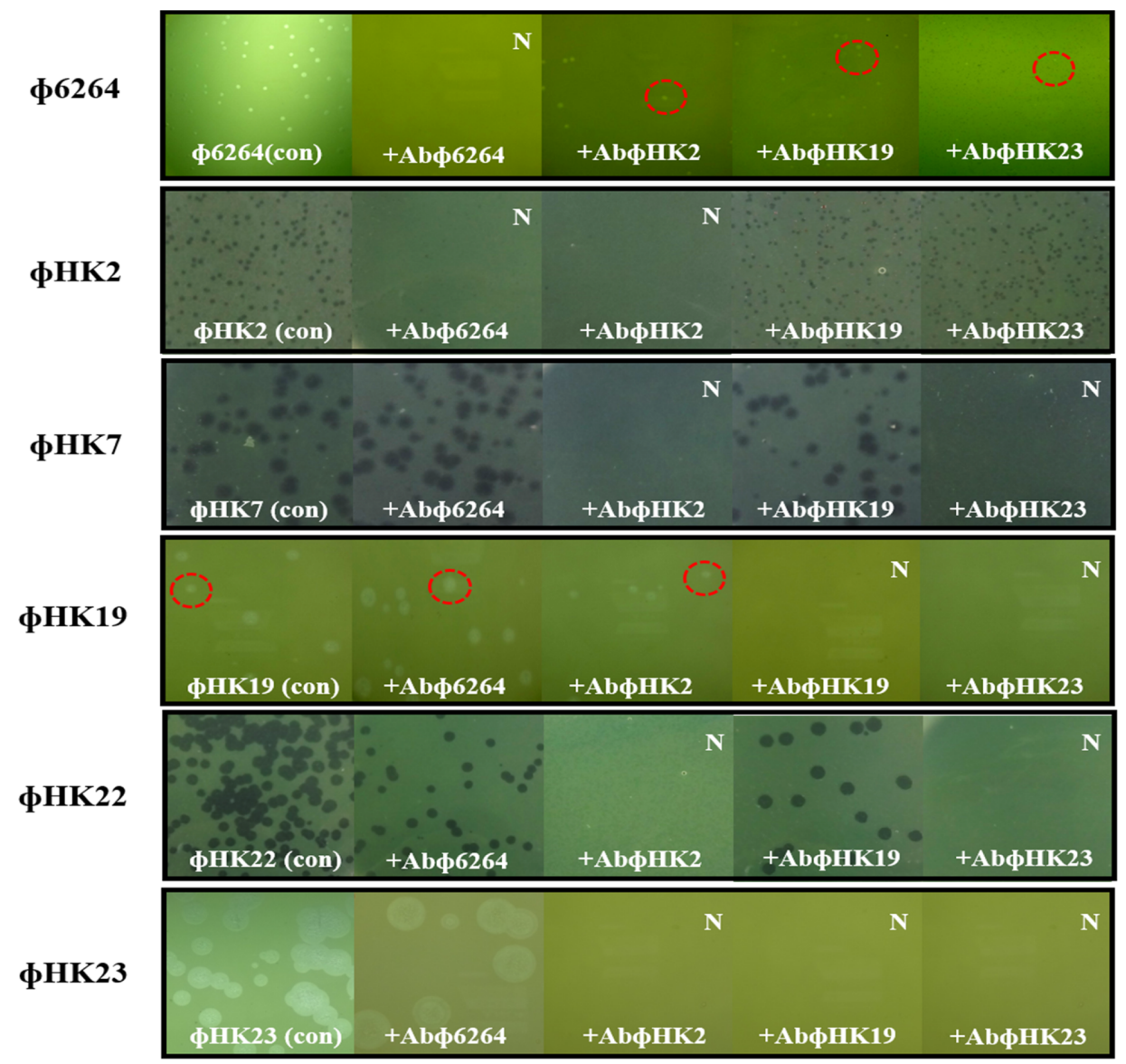

Fig. 3 Effects of various polyclonal antibodies on the formation of phage plaques. Phages were inoculated with their corresponding pathogenic strains and antibodies. N, complete neutralization and no plaque formation; red circle, example of tiny plaque formed by phage

\section{항체에 의한 파지의 불활성화}

다클론항체는 각 소분류별 갈반병 균주에 특이적인 파지들을 순 수분리한 후, 이들을 항원으로하여 생성시켰지만 파지의 표면 capsid 단백질 구조가 같거나 유사할 경우 다른 종류의 파지들 에도 특이적으로 결합하여 파지를 불활성화시킬 수 있다[9]. 따 라서, 한 가지 항체를 여러 파지에 처리하여 파지에 대한 불활 성화 효과를 측정함으로써 항원으로 사용한 파지와 그 외 다양 한 파지 사이에 구조적 유연관계를 측정할 수 있다.

선발한 8 가지의 파지들과 4 종류의 다클론항체를 각각 교차반 응시켰다. 먼저, 파지 $\phi 6264$ 의 경우는 자신의 항체인 Ab 46264 에 의해 완벽하게 불활성화되어 파지에 의한 용균반이 생성되 지 않았고, 나머지 다른 항체들에 의해서는 $\phi 6264$ 의 활성이 억
제되지 않았다. 항체에 따라 파지의 활성이 약간 감소하는 것 이 관측되었으나, 이는 파지와 항체의 비선택적 결합에 의한 것 으로 여겨진다. 파지 $\phi 6264$ 의 용균반 크기는 항체 $\mathrm{Ab \phi HK23}$ 을 처리하였을 때 작아졌으나, 파지의 활성을 완전히 억제하지는 않았다(Fig. 3, top). 파지 $\phi \mathrm{HK} 1$ 과 $\phi \mathrm{HK} 2$ 는 항체 $\mathrm{Ab} \phi 6264$ 에 의해서 불활성화 되었고, 이는 파지 $\phi \mathrm{HK} 1$ 과 $\phi \mathrm{HK} 2, \phi 6264$ 의 capsid 단백질이 구조적으로 유사한 성분을 포함함을 보여준다. 세 가지 파지의 각 숙주균이 모두 $\mathrm{P} 1 \alpha$ 소그룹에 속하여 밀접 한 연관이 있기에 이들의 파지 사이에도 구조적인 연관성이 있 을 것으로 여겨지는 결과이다. 같은 소그룹에 속하는 파지 $\phi \mathrm{HK} 2$ 는 자신의 항체인 $\mathrm{Ab} \phi \mathrm{HK} 2$ 와 같은 소그룹의 $\mathrm{Ab \phi 6264}$ 에 의해서만 저해되었다. 
$\mathrm{P} 1 \beta$ 소그룹에 속하는 파지 $\phi \mathrm{HK} 7$ 과 $\phi \mathrm{HK} 16, \phi \mathrm{HK} 19, \phi \mathrm{HK} 22$ 들이 반응하는 항체의 양상은 파지마다 다른 경향을 보였다(Fig. 3 ). 먼저 파지 $\phi \mathrm{HK} 7$ 과 $\phi \mathrm{HK} 22$ 는 숙주균이 $\mathrm{P} 1 \beta$ 균주 소그룹에 속하는 파지들임에도 $\mathrm{P} 1 \alpha$ 그룹 파지의 항체인 $\mathrm{Ab} \phi \mathrm{HK} 2$ 와 $\mathrm{P} 1 \gamma$ 그룹 파지의 항체인 $\mathrm{Ab} \phi \mathrm{HK} 23$ 에 의해 억제되었다. 반면, 파지 $\phi \mathrm{HK} 16$ 은 $\mathrm{Ab} \phi 6264$ 와 $\mathrm{Ab} \phi \mathrm{HK} 23$ 과 반응하였다. 이들 세가지 파 지들은 같은 소그룹의 항체인 $\mathrm{Ab \phi HK} 19$ 와는 반응하지 않았고 다른 두 그룹의 항체와는 결합하였다. 파지 $\phi \mathrm{HK} 19$ 는 자신의 항체인 $\mathrm{Ab} \phi \mathrm{HK} 19$ 와 $\mathrm{Ab} \phi \mathrm{HK} 23$ 과 반응하였다. 재미있게도 $\mathrm{P} 1 \beta$ 소그룹에 속하는 4 가지 파지 모두가 $\mathrm{P} 1 \gamma$ 균주에서 유래한 파지 의 항체 $\mathrm{Ab \phi HK} 23$ 에 의해 불활성화된 것은 그들이 속한 소그 룹 P1 $\beta$ 보다도 다른 소분류로 분류된 $\mathrm{P} 1 \gamma$ 그룹의 파지와 외부 단백질에 구조적 연관성이 공통적으로 있음을 의미한다.

파지 $\phi \mathrm{HK} 23$ 은 $\mathrm{Ab} \phi \mathrm{HK} 2$ 와 $\mathrm{Ab} \phi \mathrm{HK} 19, \mathrm{Ab} \phi \mathrm{HK} 23$ 에 의해 완 벽하게 중화되어, 모든 소그룹에 속한 항체에 의해 저해되는 유 일한 파지로 확인되었다. 그러나, 또 다른 $\mathrm{P} 1 \alpha$ 그룹 항체인 $\mathrm{Ab \phi 6264}$ 에 의해서는 저해되지 않았지만 사용된 파지 중 $\phi \mathrm{HK} 23$ 은 다른 파지들과 가장 넓은 구조적 유사성을 갖는 것으로 확 인되었다.

\section{항체와 파지의 교차반웅성}

4 가지 항체와 8 가지 파지들의 항체 반응을 정리하면 Table 1 과 같다. 먼저, $\mathrm{P} 1 \alpha$ 그룹에 속하는 항체인 $\mathrm{Ab} \phi 6264$ 는 $\mathrm{P} 1 \alpha$ 에 속하는 3 가지 파지 모두를 불활성화시켜, 이 그룹에 속하는 다 른 항체인 $\mathrm{Ab} \phi \mathrm{HK} 2$ 보다 $\mathrm{P} 1 \alpha$ 항원에 대한 반응성이 넓었다. 그

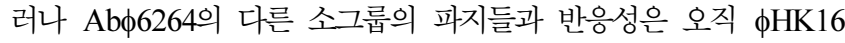
에서만 나타나, 다른 소그룹의 일부 파지와 반응하는 $\mathrm{Ab \phi HK2}$ 보다 오히려 좁은 반응성을 보였다. $\mathrm{P} 1 \beta$ 그룹의 항체 $\mathrm{Ab} \phi \mathrm{HK} 19$ 는 항원으로 사용한 파지 $\phi \mathrm{HK} 19$ 와 $\mathrm{P} 1 \gamma$ 에 속하는 파지 $\phi \mathrm{HK} 23$ 과만 반응하였다. 그러나 파지 $\phi \mathrm{HK} 23$ 은 모든 $\mathrm{P} 1 \beta$ 그룹 파지 들을 중화시켜 항체 중에 가장 많은 항원들과 반응하였지만 $\mathrm{P} 1 \alpha$ 그룹의 파지들과는 전혀 결합하지 않았다. 이러한 결과는 $\phi \mathrm{HK} 23$ 의 capsid 단백질 구조가 $\mathrm{P} 1 \beta$ 와 $\mathrm{P} 1 \gamma$ 파지들과 가장 넓 은 연관성을 보여주는 결과이다.

이상의 분석을 포함한 파지와 항체의 교차반응성을 도식화하 였을 때, Fig 4에서 다양한 겹침으로 나타난 교차반응성은 파 지들간의 구조적인 유사성의 연관관계를 보여준다. 파지의 구조 적인 유사성의 양상은 $16 \mathrm{~S} \mathrm{rRNA}$ 유전자 분석에 의한 분류와 는 차이를 보여주어, 파지의 숙주균이 유전적으로 유사하더라도 숙주균의 세포막에 흡착하여 균주를 용균시키는 파지의 구조는 매우 다를 수 있음을 나타낸다. 교차반응의 정도로 볼 때, $\mathrm{Ab} \phi 6264$ 보다는 $\mathrm{Ab} \phi \mathrm{HK} 2$ 와 $\mathrm{Ab} \phi \mathrm{HK} 19, \mathrm{Ab} \phi \mathrm{HK} 23$ 항체들이 파 지들과의 교차반응성을 더 많이 보이고 있어 반응성에 차이가 있음을 확인할 수 있다. 이것은 다클론항체가 인식하는 파지의 구조가 다양하며, $16 \mathrm{~S}$ rRNA 유전자 분석으로는 나타난 숙주균 의 근연관계와 숙주균에 따른 파지의 근연관계와는 상당히 다 름을 알 수 있다[15].

본 연구에서 사용한 숙주균의 분류는 $16 \mathrm{~S} \mathrm{rRNA}$ 유전자 염 기서열을 비교하여 이루어졌다[8]. $16 \mathrm{~S}$ rRNA 유전자 염기서열 분석을 통한 세균의 분류는 보편적인 방법이나, 갈반병을 유발 하는 P. tolaasii 변이균주들은 유전적으로 매우 유사하기에 각 변이균주들의 병원 특성을 잘 나타내진 않는다[15-17]. 기존의

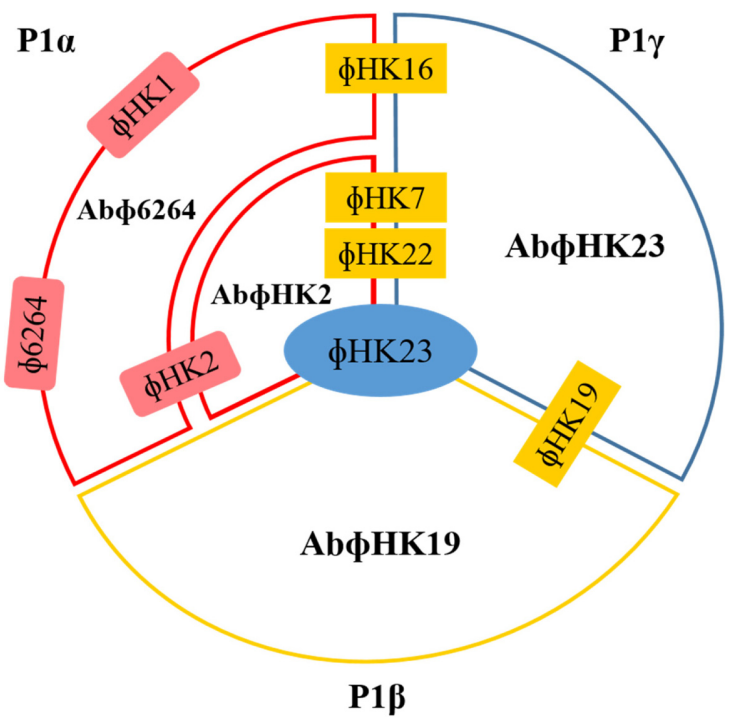

Fig. 4 Schematic diagram of cross-reactivities between phages and polyclonal antibodies. Red: P1 $\alpha$ phages and their antibodies, Yellow: P1 $\beta$ phages and antibody, Blue: P1 $\gamma$ phage and its antibody

연구에서 갈반병 변이균주들의 병원성 차이는 버섯조직함몰검 정법, 적혈구 용혈활성, 톨라신 침강법의 세 가지 방법으로 확 인하였다. 유전자를 분석하여 얻은 동일한 소그룹의 균주들은 세가지 병원성 측정에서 같은 경향을 보여 유전자 구조에 따른 분류와 각 그룹별 병원성 특성에는 큰 연관성이 있음을 확인하 였다 $[8,18]$. 그러나, 파지 항체에 대한 반응성을 이용한 숙주균 의 분류는 유전자 염기서열에 따른 분류와 차이를 보였다[19]. Fig. 4에서는 각 소그룹에 특이적인 파지와 항체사이에 반응성 을 나타냈다. 소그룹에 속하는 파지들과 항체의 상호 반응성을 분석하면 유전자 염기서열에 따른 소그룹 파지의 종류와 무관 하게 항체는 다양한 파지와 반응함을 확인하였다. 예를 들면, $\mathrm{P} 1 \gamma$ 그룹의 파지 $\phi \mathrm{HK} 23$ 은 3 가지 다른 항체와 반응하였고, $\mathrm{P} 1 \beta$ 에 속하는 $\phi \mathrm{HK} 16, \phi \mathrm{HK} 7, \phi \mathrm{HK} 22$ 파지들은 $\mathrm{P} 1 \alpha$ 와 $\mathrm{P} 1 \gamma$ 항체 들과 반응하나 오히려 $\mathrm{P} 1 \beta$ 항체와는 반응하지 않았다. 이 결과 는 서로 다른 소그룹 균주에 특이적인 파지임에도 불구하고 유 전자 염기서열에 따른 분류와는 다르게 다클론항체에 의해 인 식되는 부위를 공유하고 있음 보인다[20,21]. 따라서, 균주 및 파지, 항체 사이의 관계는 파지의 형태학적 특성, 파지에 대한 항체의 인식 부위 $[9,22]$ 등에 따라 결정되는 것으로, 균주의 $16 \mathrm{~S}$ rRNA 염기서열에 따른 분류와는 관련이 적은 것을 확인 하였다.

\section{초 록}

Pseudomonas tolaasii는 느타리버섯에 갈반병을 일으키는 병원 균주로, 다양한 변이균주들을 분리하여 $\mathrm{P} 1 \alpha$ 와 $\mathrm{P} 1 \beta, \mathrm{P} 1 \gamma$ 세 가 지 소그룹으로 분류하였다. 각 그룹별 균주들에 특이적인 박테 리오파지를 이용한 파지테라피는 갈반병 방제에 매우 성공적이 었다. 본 연구에서는, 박테리오파지들의 특성을 구명하기 위하 
여 소그룹별 대표균주을 이용하여 파지를 분리하였고, 이들의 다클론항체를 제작하여 파지들 사이에 유연관계를 조사하였다. 파지 준비물은 $10^{10} \mathrm{pfu} / \mathrm{mL}$ 이상으로 토끼의 다리 근육에 주사 하였고, 3 회의 반복주사에 의해 다클론항체가 얻어졌다. 파지 $\phi 6264$ 에 대한 항체의 역가는 $2 \times 10^{7} \mathrm{Ab} / \mathrm{mL}$ 이상, 파지 $\phi \mathrm{HK} 2$ 에 대해서는 $1 \times 10^{6} \mathrm{Ab} / \mathrm{mL}$, 파지 $\phi \mathrm{HK} 19$ 와 $\phi \mathrm{HK} 23$ 에 대해서 는 $1 \times 10^{7} \mathrm{Ab} / \mathrm{mL}$ 이상이었다. 항체와 이에 특이적인 파지 사이 에는 매우 높은 반응특이성이 있었고, 소그룹이 다른 파지의 항 체와 파지 사이에도 일부 교차반응성을 확인하였다. 파지 $\phi 6264$ 에서 생성된 $\mathrm{Ab} \phi 6264$ 는 모든 $\mathrm{P} 1 \alpha$ 소그룹의 파지들과 반응성 을 보였으나, 파지 $\phi \mathrm{HK} 16$ 을 제외한 다른 소그룹의 파지들과는 반응하지 않았다. $\mathrm{P} 1 \gamma$ 소그룹에서 생성된 $\mathrm{Ab} \phi \mathrm{HK} 23$ 은 $\mathrm{P} 1 \beta$ 소 그룹의 모든 파지들을 불활성화시켜 가장 넓은 항체범위를 보 였다. 항체와 파지를 이용한 숙주균과의 관계를 분석하였을 때, $16 \mathrm{~S} \mathrm{rRNA}$ 유전자 분석에 의한 숙주균의 근연관계와 항체를 이 용한 숙주균의 파지들 사이의 구조적 근연관계는 상당히 차이가 있음을 확인하였다. 결론적으로, 박테리오파지의 숙주균 특이성 과 항체를 이용해 측정한 파지의 껍질단백질 구조유사성 사이 에는 약한 상관성을 보였다.

Keywords 갈반병 · 근연관계 · 박테리오파지 · 숙주역 · 항체 - Pseudomonas tolaasii

감사의 글 이 논문은 2017 년도 정부(교육부)의 재원으로 한국연구재단의 지원을 받아 수행된 기초연구사업임(No. 2017R1D1A3B03032718).

\section{References}

1. Tolera KD, Abera S (2017) Nutritional quality of oyster mushroom (Pleurotus ostreatus) as affected by osmotic pretreatments and drying methods. Food Sci Nutr 5: 989-996

2. Visioli F, Poli A, Richard D, Paoletti R (2008) Modulation of inflammation by nutritional interventions. Curr Atheroscler Rep 10: 451-453

3. Schneider I, Kressel G, Meyer A, Krings U, Berger RG, Hahn A (2011) Lipid lowering effects of oyster mushroom (Pleurotus ostreatus) in humans. J Funct Foods 3: 17-24

4. Rainey PB, Brodey CL, Johnstone K (1991) Biological properties and spectrum of activity of tolaasin, a lipodepsipeptide toxin produced by the mushroom pathogen Pseudomonas tolaasii. Physiol Mol Plant Pathol 39: $57-70$

5. Wells JM, Sapers GM, Fett WF, Butterfield JE, Jones JB, Bouzar H, Miller FC (1996) Postharvest discoloration of the cultivated mushroom Agaricus bisporus caused by Pseudomonas tolaasii, P. reactans, and $P$. gingeri. Phytopathology 86: 1098-1104

6. Kortright KE, Chan BK, Koff JL, Turner PE (2019) Phage therapy: A renewed approach to combat antibiotic-resistant bacteria. Cell Host
Microbe 25: 219-232

7. Lin DM, Koskella B, Lin HC (2017) Phage therapy: An alternative to antibiotics in the age of multi-drug resistance. World $\mathrm{J}$ Gastrointest Pharmacol Ther 8: 162-173

8. Yun YB, Park SW, Cha JS, Kim YK (2013) Biological characterization of various strains of Pseudomonas tolaasii that causes brown blotch disease. J Korean Soc Appl Biol Chem 56: 41-45

9. Haji-Ghassemi O, Blackler RJ, Young NM, Evans SV (2015) Antibody recognition of carbohydrate epitopes. Glycobiology 25: 920-952

10. Yun YB (2013) Characterization of Pseudomonas tolaasii strains and their bacteriophages for the biological control of brown blotch disease. Dissertation, Chungbuk National University

11. Santos SB, Carvalho CM, Sillankorva S, Nicolau A, Ferreira EC, Azeredo J (2009) The use of antibiotics to improve phage detection and enumeration by the double-layer agar technique. BMC Microbiol 9: 148

12. Chibani-Chennoufi S, Sidoti J, Bruttin A, Kutter E, Sarker S, Brussow H (2004) In vitro and in vivo bacteriolytic activities of Escherichia coli phages: Implications for phage therapy. Antimicrob Agents Chemother 48: $2558-2569$

13. Leenaars M, Hendriksen CF (2005) Critical steps in the production of polyclonal and monoclonal antibodies: Evaluation and recommendations. ILAR J 46: 269-279

14. Halliday LC, Artwohl JE, Bunte RM, Ramakrishnan V, Bennett BT (2004) Effects of Freund's complete adjuvant on the physiology, histology, and activity of New Zealand White rabbits. Contemp Top Lab Anim Sci 43: 8-13

15. Poretsky R, Rodriguez-R LM, Luo C, Tsementzi D, Konstantinidis KT (2014) Strengths and limitations of 16S rRNA gene amplicon sequencing in revealing temporal microbial community dynamics. PLoS ONE 9: e93827

16. Clarridge JE (2004) Impact of $16 \mathrm{~S}$ rRNA gene sequence analysis for identification of bacteria on clinical microbiology and infectious diseases. Clin Microbiol Rev 17: 840-862

17. Jo JH, Kennedy EA, Kong HH (2016) Research techniques made simple: Bacterial 16S ribosomal RNA gene sequencing in cutaneous research. J Invest Dermatol 136: e23-e27

18. Mu LL, Yun YB, Park SJ, Cha JS, Kim YK (2015) Various pathogenic Pseudomonas strains that causes brown blotch disease in cultivated mushrooms. J Appl Biol Chem 58: 349-354

19. Żaczek M, Łusiak-Szelachowska M, Jończyk-Matysiak E, WeberDąbrowska B, Międzybrodzki R, Owczarek B, Kopciuch A, Fortuna W, Rogóż P, Górski A (2016) Antibody production in response to staphylococcal MS-1 phage cocktail in patients undergoing phage therapy. Front Microbiol 7: 1681

20. Shi E, Fury W, Li W, Mikulka W, Aldrich T, Rafique A, Chen G, Hoffenberg S, Daly TJ, Radziejewski C (2006) Monoclonal antibody classification based on epitope-binding using differential antigen disruption. J Immunol Methods 314: 9-20

21. Sela-Culang I, Kunik V, Ofran Y (2013) The structural basis of antibodyantigen recognition. Front Immunol 4: 302

22. Pratihar S, Sabo TM, Ban D, Fenwick RB, Becker S, Salvatella X, Griesinger C, Lee DH (2016) Kinetics of the antibody recognition site in the third IgG-binding domain of protein G. Angew Chem Int Ed Engl 55: 9567-9570 